\title{
Awareness and Uptake of Cervical Cancer Screening in Owerri, South-Eastern Nigeria
}

\author{
B. U. Ezem \\ Department of Obstetrics and Gynaecology, Imo State University Teaching Hospital, Orlu, Nigeria \\ Reprint requests to: Dr. B. U. Ezem, Department of Obstetrics and Gynaecology, Imo State University Teaching \\ Hospital, P. M. B. 8,Orlu, Nigeria.E-mail: firstezem@yahoo.com
}

\begin{abstract}
Background: Cancer of the cervix is the most common cancer of the female genital tract and accounts for about two hundred and fifty thousand deaths yearly most of which occur in the developing countries. It has assumed greater prominence with the decrease in deaths due to infective causes and the increase in the incidence of HIV/AIDS which is a predisposing factor. A significant drop in its incidence has been recorded in the developed countries as a result of intensive program of cervical screening. This study determines the level of awareness and uptake of cervical screening in Owerri, South Eastern part of Nigeria.

Method: This is a cross sectional study in which self administered questionnaires returned by eight hundred and forty six respondents were analysed using simple percentages.

Results: The level of awareness of cervical screening was $52.8 \%$ (447), while $7.1 \%(60)$ had ever done the test. The major sources of information about cervical smear were hospital /health facilities $(31.3 \%)$ and friends $(30.9 \%)$.The most common reasons given for not doing the test were lack of awareness $390(46.1 \%)$,no need for it 106( 12.5\%) and fear of a bad result 98(11.6\%).

Conclusion: The level of awareness of cervical screening is low and worse still, is the level of uptake at the present level of uptake no significant impact will be made on the incidence of cervical cancer which needs to be reduced. A national cervical smear screening policy is advocated but in the interim, greater public education and the greater use of opportunistic screening by physicians should be vigorously pursued.
\end{abstract}

Key words: Cancer, cervical screening, awareness, uptake

\section{Résumé}

Introduction: Le cancer du cou est le cancer le plus ordinaire de la voie génitale du sexe féminin et il constitue environs deux cents cinquante mille des morts annuelle dont la plupart arrivent dans les pays en voie de développement. Présumé une plus grande éminence avec un ralentissement des morts attribuables aux causes infectives et à un accroissement dans la fréquence de VIH/SIDA qui est un facteur possible. Une baisse remarquable dans sa fréquence a été notée dans les pays développé à la suite du programme intensif du test de dépistage cervical. Cette étude décide le niveau de la conscience et l'esprit vif d'un test de dépistage à Owerri Sud Est du Nigéria.

Méthode: Il s'agit d'une étude d'un groupe répresentatif dont des questionnaires soi-fait et returné par huit cents et quarante six sondés ont été analysés à travers l'utilisation du pourcentage simple.

Résultats: Le niveau de la conscience d'un test de dépistage cervical était 52,8\% (447), tandis que 7,1\% (60) avaient déjà fait le test. La source principale pour avoir des informations à propos du couler cervical étaient hôpital et aménagement sanitaire $(31,3 \%)$ et amis $(30,9 \%)$. Des raisons le plus ordinaires données pour ne pas faire du test étaient manque de la conscience $390(46,1 \%)$ pas d'importance $106(12,5 \%)$ et la peur d'un mauvais résultat $98(11,6 \%)$.

Conclusion: Le niveau de la conscience du test de dépistage cervical est bas et mauvais encore, c'est le niveau l'esprit vif dans le niveau actuel d'esprit vif, il n'y a aucun impact remarquable qui peut être réalisé dans la fréquence du cancer du cou qu'on doit nécéssairement reduire. Une politique nationale sur le test de dépistage du couler cervical est éxigée mais entre-temps, message de grande cause nationale et l'utilisation d'une grand test de dépistage opportnistique par des médecins devraient être vigoureusement atteint/recherché.

Mots-clés: Le cancer, dépistage cervical, la conscience, l'esprit vif d'un test 


\section{Introduction}

Cancer of the cervix is the commonest genital tract malignancy in the female. ${ }^{1}$ It is even more important in the developing countries where it used to be the most common malignant disease. 2,3 Recently however it has been ranked second to breast cancer in some studies. ${ }^{4-7}$ About half a million new cases are seen world wide each year most occurring in developing countries where they present late ${ }^{8,9}$ when only palliative treatment can be given. ${ }^{10}$ Cancer is responsible for about 51 million deaths yearly out of which cervical cancer accounts for $8.5 \%$ most of which occur in the developing countries. ${ }^{11}$ In Nigeria the national incidence of cervical cancer is 250/100,000. ${ }^{12}$

With the decline in death from infective causes, the increasing permissiveness of the society fueling the HIV/AIDS pandemic 13 the relative incidence of cancer of the cervix is on the increase. Unfortunately anything approaching adequate treatment is only available in a few centers at costs beyond the reach of many of the afflicted. ${ }^{16}$ This is amply illustrated by the fact that by the year 2004 only three radiotherapy units were available to serve a population of 130 million Nigerians. ${ }^{15}$

The long transition time from a premalignant lesion to frank cancer of the cervix affords ample time for early detection and nearly complete cure even in secondary health care centers. However this window of opportunity which has enabled the developed countries to reduce the incidence of cancer of the cervix 16 would be wasted if the level of screening is low. In this paper we determine the level of awareness of, and the uptake of cervical cancer screening in South Eastern Nigeria a highly populated part of Nigeria, using Owerri as a case study.

\section{Materials and Methods}

The study was carried out in Owerri, Nigeria, between January 2004 and June 2004.Owerri is the capital of Imo State, which is one of the nine states in the South Eastern part of Nigeria. It has a population of two hundred and ninety thousand and is inhabited largely by Ibos, one of the three major ethnic groups in Nigeria. Until 1976 when the Imo State was created, Owerri was a typical sleepy rural town made up of five indigenous villages. With the creation of Imo State and its choice as the capital, the population mushroomed due to the influx of public servants and businessmen from other parts of the state. The socioeconomic activity revolves around the government as Owerri has virtually no industries. It is however highly favoured educationally as it boasts of two universities, a polytechnic, and a college of education among others.

There is no organized government screening policy, screening being offered at the request of patients or the suggestion of health personnel by gynecologists.
A multistage cluster sample approach was used in this study. Owerri town is divided into seventeen political wards. Four out of these were randomly selected for logistic reasons and to minimize cost. Each of the wards is divided into ten chapters .Four chapters were again randomly selected from each of the four wards previously selected. The research assistant visited households in the four selected chapters and distributed two hundred and fifty questionnaires to willing women aged between twenty and sixty five years. The questionnaires were pretested on twenty respondents who were not included in the study. The minimum sample size of three hundred and eighty four was determined according to Kregcie and Morgan. ${ }^{17}$

Each questionnaire was semi structured, contained seventeen questions and elicited information on respondent's biodata, education and occupation. It also sought information about knowledge, awareness, uptake source of information and reasons for not doing cervical smear, where applicable. Most of the women completed the questionnaires without assistance. A few who had difficulties were assisted by the research assistant .Data analysis was by use of simple percentages.

\section{Results}

Eight hundred and forty six of the returned questionnaires were suitable for analysis. They were from public servants 460,teachers 246,nurses 72 ,administrators 20,self employed 20,students 3.Twenty five(25) respondents did not state their occupations. Three hundred and sixty $(42.6 \%)$ of the respondents were aged between 20 and 40 years, while 396(46.8\%) were between 40 and 65 years, and $90(10.6 \%)$ did not state their ages. Single women were112 (13.2\%) while the rest were married.The study population was predominantly Christian 800 (94.6\%). Nulliparous women (102) constituted 12.1\%, while $384,(45.4 \%)$ had $1-4$ children and $336(39.7 \%)$ had greater than four children 24 respondents $(2.8 \%)$ did not state their parity.

Six hundred and thirty $(74.5 \%)$ had tertiary education, $124(14.7 \%)$ had secondary education while $24(2.8 \%)$ did not indicate their educational status $.447(52.8 \%)$ of the respondents were aware of cervical screening, 390 (46.1\%) were unaware while 9 did not answer the question (Table1).

Amongst the respondents (447) who were aware of screening $140(31.3 \%)$ got their information from hospital sources while $138 \quad(30.9 \%)$ got their information from friends, and 94(21\%) from books or magazines (Table 2).Only five got their information from relations who had had carcinoma of the cervix.

Only $60,(7.1 \%)$ of the respondents had ever done the test and most of these were done over three years ago.

The reasons for the lack of uptake (Table 3) included lack of awareness390 (46.1\%), no need for it 106 $(12.5 \%)$ and fear of a bad result $98(11.6 \%)$. 
Table 1: Level of awareness of cervical smear among 846 respondents

\begin{tabular}{ll}
\hline Level of awareness & No. $(\%)$ \\
\hline Previously aware of the test & $447(52.8)$ \\
Previously unaware of the test & $390(46.1)$ \\
Not stated & $9(1.1)$ \\
\hline Total & $846(100)$ \\
\hline
\end{tabular}

Table 2: Sources of information about cervical screening among 448 respondents

\begin{tabular}{ll}
\hline Source of information & No. $(\%)$ \\
\hline Hospital & $140(31.3)$ \\
Friends & $138(30.9)$ \\
Books/magazines & $94(21.0)$ \\
School & $40(8.9)$ \\
Husband & $13(2.9)$ \\
Television/radio & $10(2.2)$ \\
Others & $13(2.8)$ \\
\hline Total & $448(100)$ \\
\hline
\end{tabular}

Table 3: Reasons for not doing cervical smear among 846 respondents

\begin{tabular}{ll}
\hline Reason & No. $(\%)$ \\
\hline Lack of awareness & $390(46.1)$ \\
Saw no need for it & $106(12.5)$ \\
Don't know it can be done here & $98(11.6)$ \\
Fear of bad result & $98(11.6)$ \\
Not recommended by doctor & $46(5.4)$ \\
Too expensive & $465.4)$ \\
Others & $35(4.1)$ \\
Not stated & $27(3.3)$ \\
\hline Total & $846(100)$ \\
\hline
\end{tabular}

\section{Discussion}

At every stage in life, a woman in the third world risks some serious health problems. These include HIV/AIDS, high maternal mortality rates, and cancer of the cervix later in life. Cancer of the cervix is a preventable disease and a key aspect of its prevention is the detection of the premalignant form by cervical screening.

The major findings of this study are that $52.8 \%$ of the respondents were aware of cervical screening and that $7.1 \%$ had ever done the test. .It also finds that most of those who were aware of screening got their information from hospital sources $(31.3 \%)$ and friends $(30.9 \%)$. The major reasons for not doing the test cited by those who were aware of it were 'no need for it', lack of knowledge that it could be done locally, and fear and anxiety over a positive result.

The major drawback of the study is that the high percentage $(74.5 \%)$ of respondents who had tertiary education would not normally be expected in a typical population in a developing country. Robert et al ${ }^{18}$ found a positive relationship between education and awareness of cervical screening. This would suggest that the level of awareness could be lower than was found in this study in other parts of the state where the level of education is lower.

The level of awareness of $52.8 \%$ found in this study is less than $69.8 \%$ from Ilorin 19 and $70 \%$ in Ibadan ${ }^{20}$ but is much higher than what is found in other parts of Nigeria $18,21,22$ or $39 \%$ in Ghana. ${ }^{23}$ It is also much lower than what obtains in developed countries. ${ }^{25}$ The differences in the levels of awareness may be partly explained by educational status. ${ }^{18}$ The highest levels of awareness are from studies using undergraduates and health care professionals while the lowest levels come from studies using commercial sex workers and clinic attendees. Educational level would however not explain the figure from Ghana as the respondents were said to be well educated women.

There was greater concordance among the various local studies in the percentage of women who had ever done the test. There was an overall very poor uptake of screening irrespective of education and level of awareness, which ranged between $0.3 \%$ and $8.5 \%$. ${ }^{18-23,25}$ This level of uptake of screening is clearly unsatisfactory and worrisome as it will make no significant impact on the prevalence of cervical cancer as screening of highest level and coverage 24 is needed for any meaningful impact on the incidence of cervical cancer. It has been suggested that one way of correcting this is for health care workers to show good example which the populace can copy. ${ }^{19}$

Lack of awareness, being unnecessary, fear and anxiety were cited as the major reason for not doing the test in $46.1 \%, 12.5 \%$ and $11.6 \%$ respectively of the respondents. In the study from Ilorin ,Nigeria 19 where unlike our study population there is a preponderance of Muslims, the reasons cited for not doing the test were unavailability of the test, fear of detection of cancer and it's being against religious beliefs in $52.5 \%, 19.2 \%$ and $14.6 \%$ of those studied. This reveals a lack of appreciation of the disease, and the failure of the health system to effectively disseminate information. Fear and anxiety associated with a bad result stems from the poor understanding of the principle behind cervical screening. Our women would rather live in blissful ignorance than know that they have a disease where adequate treatment is practically non existent, unaffordable and results of treatment poor. ${ }^{26}$ This situation could be reversed by better public enlightenment highlighting the fact that a premalignant lesion can be completely cured. Hospital sources $(31.3 \%)$ were the major source of information in this study. This is similar to the results of some studies ${ }^{18,21}$ but is different from other studies where radio and $\mathrm{TV}{ }^{22}$ or lectures and textbooks ${ }^{20}$ were the main sources of information.

That screening prevents deaths is not in doubt. ${ }^{27}$ This has reduced the scourge of this disease in advanced countries. However low income countries are unlikely to be able to mount screening programmes as sophisticated as those in the developed countries for some time to come. A national screening policy has been advocated, ${ }^{28,} 29$ but while we wait for this, greater public awareness 
should be created and greater use should be made by physicians of opportunistic cervical screening as presently even amongst Nigerian gynaecologists only $15 \%$ request for cervical screening of their patients 28 while $76.9 \%$ of those who did a cervical smear did so because a health worker asked them to do it. ${ }^{19}$ In addition, modified strategies like limited pap screening, ${ }^{29}$ single visit approach ${ }^{30}$ and visual inspection with acetic acid application $31,-33$ should be used as stop gap measures.

\section{References}

1. Adefuye PO. Knowledge and practice of cervical screening among professional health workers in a suburban district in Nigeria. Nigerian Medical Practitioner 2006;50:19-22

2. Mandong BM. Malignant disease in Jos University Teaching Hospital. Nigerian Medical Practitioner 1999; 37:55-56

3. Duncan JTK. Radiotherapeutic management of cancer of the cervix in Nigeria. Ghana Med J $1973 ; 12: 374$

4. Campbell OB, Adu FD, Danwatta FD. Human immunodeficiency virus antibody positivity in cancer patients undergoing radiotherapy in Ibadan: clinical findings, pathogenesis and therapy. Nigerian Medical Journal 1997;32:90-92

5. Solanke TF. An overview of cancer in Nigeria. In: Solanke TF, Adebamowo CA (eds). Report of a workshop on state of the art in oncology in Ibadan and Ife. National Headquarters of Cancer Registries in Nigeria, Ibadan,1996;7-12

6. Adebamowo CA, Ajayi OO, Breast cancer in Nigeria. West Afr J Med 2000;19:179-194

7. Madong BM, Madaka AKJ, Mannaseh AN. Malignant disease in Jos: a follow up. Ann Afr Med 2003;2:48-53

8. Ezem BU, Katchy KC. Carcinoma of the cervix in Northern Nigeria. Asia Oceania J Obstet Gynecol 1982;18: 385-389

9. Jimoh AS, Abdul IF. A review of one hundred and three (103) histologically confirmed cases of carcinoma of the cervix at the University of Ilorin Teaching Hospital, Nigeria. Nigerian Medical Practitioner 2004;45: 55-60

10. Durosinmi-Etti FA. Cancer patients in Nigeria: causes of delay in diagnosis and treatment. Nigerian Quarterly Journal of Hospital Medicine 1985;3:28-30

11. Hakulinen T, Hanshuwka H, Lopez AD, et al Global and regional mortality pattern by cause of death in 1980. Int J Epidemiol 1986;15:227-233

12. Adewole IF, Edozien EC, Babarinsa IA, et al. Invasive and in situ carcinoma of the cervix in young Nigerians. A clinico-pathologic study of 27 cases. Afr J Med Sci 1997;26:191-193

13. Mandelblatt JS, Fahs M, Garibalo IK, et al. Association between HIV infection and cervical neoplasia. Implications for clinical care of the women at risk for both conditions. AIDS $1992 ; 6: 173-178$
14. Hansen GP, Stjernsward J, Norfal M, et al. An overview of the situation in radiotherapy with emphasis on developing countries. Int J Radiation Oncol Biol Physics 1990;19:1257-1261

15. Dawtola DA, Olaseinde TA, Radiotherapy in cancer management at Ahmadu Bello University Teaching Hospital (ABUTH) Zaria, Nigeria. Assessment of clinical impact of new radiotherapy facilities. Nigerian Medical Practitioner 2004;45: 45-48

16. Hakama M, Joutsenlahti U, Virtaren A, et al. Mass screening for cervical cancer in Finland 1963-71. Organization, extent and epidemiological implications. Ann Clin Res 1975;7:101-111

17. Krejcie RV, Morgan DW. Determining sample size for research activities. Educational and Psychological Measurements 1970;30:607-610

18. Roberts AA, Anyakogbe OO, Osisanya TF, et al. Knowledge of cervical risk factors among refugee women in Oru camp. Nigerian Medical Practitioner 2004;46:67-70

19. Aboyeji PA, Ijaiya MA, Jimoh AA. Knowledge, attitude and practice of cervical smear as a screening procedure for cervical cancer in Ilorin, Nigeria. Tropical Journal of Obstetrics and Gynaecology 2004;21:114-117

20. Ayinde AE, Adewale IF, Babarinsa IA. Trends in cervical smear screening in Ibadan, Nigeria. A four year review. West Afr J Med 1998;19:25-30

21. Daramola A. A study of the awareness of screening procedure for carcinoma of the cervix (Pap smear) amongst health service users. Proceeding's of the $25^{\text {th }}$ International Congress of the Medical Women's Association, 2001

22. Onajole AT, Ajekigbe AO, Odeyemi KA, et al. The socio-demographic characteristics and level of awareness of prevention of cancer of the cervix among commercial sex workers in Lagos, Nigeria. Nigerian Medical Practitioner 2004;45:52-55

23. Adanu RMK. Cervical cancer knowledge and screening in Accra, Ghana. J Womens Health Gend Based Med 2002;11:487-488

24. Control of cervical cancer of the cervix uteri. Bull WHO 1986;64:669-673

25. Chukwuali LI, Onuigbo WIB, Mgbor MC. Cervical screening in Enugu, Nigeria. Tropical Journal of Obstetrics and Gynaecology 2003;20:109-112

26. Shafi M. Premalignant and malignant diseases of the cervix. In: Edmonds DK (ed). Dewhurst textbook of obstetrics and gynaecology for postgraduates. Blackwell, London, 1999;572-581

27. Control of cancer of the cervix uteri: Review article based on a report of a WHO meeting, November 1985, Geneva. Bull WHO 1986;64:607-618

28. Onah HE, Ezugwu FO, Eze JN. Cervical screening: a survey of current practice amongst Nigerian gynaecologists. Tropical Journal of Obstetrics and Gynaecology 2001;18:78-81

29. Hoffman M, Cooper D, Carrara H, et al. Limited 
pap screening associated with reduced risk of cervical cancer in South Africa. Int J Epidemiol 2003;32:573-577

30. Royal Thai College of Obstetricians and Gynaecologists (RTCOG) and the JHPIEGO Corporation Cervical Cancer Prevention Group. Safety, acceptability and Feasibility of a singlevisit approach to cervical cancer prevention in rural Thailand: a demonstration project. Lancet 2003;361:814-820

31. Mantelblatt JS, Lawrence WF, Gaffikin L, et al.
Costs and benefits of different strategies for cervical screening in less developed countries. J Natl Inst Cancer 2002;94:1469-1483

32. Carr KC, Sellem MW. Cervical cancer screening in low resource settings using visual inspection with acetic acid. J Midwifery Womens Health 2004;49:329-337

33. Denny L, Kuhn L, Pollack A, Wainwright H, Wright TC Jr. Evaluation of alternative methods of cervical screening for resource-poor settings. Cancer 2000;89:826-833 